\title{
STUDY ON CAUSATIVE AGENTS OF DAMAGE IN THE COSTA RICAN CARIBBEAN ARCHITECTURE FROM A MULTIDISCIPLINARY PERSPECTIVE
}

\author{
García-Baltodano, K., ${ }^{1 *}$, Porras-Alfaro, D. ${ }^{2}$ and Hernández-Salazar, I. ${ }^{2}$ \\ ${ }^{1}$ Escuela de Arquitectura y Urbanismo \\ Instituto Tecnológico de Costa Rica \\ Campus Tecnológico Local San José, San José, Costa Rica \\ e-mail: kgarcia@tec.ac.cr, www.tec.ac.cr \\ ${ }^{2}$ Instituto Tecnológico de Costa Rica \\ Campus Tecnológico Local San José, San José, Costa Rica \\ e-mail: dporras@tec.ac.cr, ihernandez@tec.ac.cr,www.tec.ac.cr
}

Keywords: vernacular architecture; Limón, Costa Rica; pathologies in buildings; inventory

\begin{abstract}
The aim of this communication is to analyze the architectural, historic and construction values of the Costa Rican Caribbean architecture, which constitutes an architectural typology of the identity of the city of Limón. Damages linked to biological agents in these buildings were identified based on the multidisciplinary research project titled "Conservation of the Costa Rican Caribbean architecture by applying advanced techniques for studying the causative agents of damage in the buildings".

An inventory of the study area was conducted in order to identify predominant elements of this type of architecture, as well as to quantify and georeference, through a Geographic Information System, the buildings that are still preserved; the identification of damage-causing agents within the inventory was also part of the process. As a second stage, samples taken from the buildings will be analyzed in the biological sciences laboratory to identify biological agents that were potentially responsible for damage.

Thirty representative buildings of the Costa Rican Caribbean architecture were identified, for which inventory records were made that included information about architectural and building aspects, as well as damage identification and classification, and types of causative agents. Based on a multi-criteria evaluation, Capitanía de Puerto, Casa Misionera de la Iglesia Bautista and other edifications were selected as the buildings to conduct the inventory of biological damage, sampling, and environmental monitoring.
\end{abstract}

\section{INTRODUCTION}

Costa Rica outstands for its diversity, including geographical as well as cultural and ethnical aspects. Despite being a small country, its regions are manifestly different from one another, which influences the way constructions for inhabiting the different spaces are made.

Costa Rican Caribbean architecture is an example of vernacular architecture which, although based on imported models, constitutes an adaptation to the spatial and bioclimatic needs of a particular zone of the country. Caribbean architecture in Costa Rica was developed 
especially in the city of Limón, between 1870 and 1940, closely linked to settlement and growth processes of this area.

For a long time, the city of Limón was the main port in Costa Rica. It was originally planned to facilitate exportation of coffee beans and was used later for banana exportation. The city was established during a period of economic booming and it was designed to accomplish ideals of modernization and hygienization associated to the prevailing liberal ideology of the time.

This city was the operations center of the United Fruit Company, a multinational company that dominated the banana market at international level. This company also created an enclave in the whole province of Limón by taking advantage of its links to the Northern Railway Company, who led the construction of the Atlantic railway and to whom Costa Rica's government granted a large extension of land as payment for the work [1].

The United Fruit Company imported catalogue buildings for a good part of the edifications, which were influenced by the Victorian Caribbean architecture. However, because of the weather conditions in Limón, of high humidity and temperature and constant rain throughout the year, these buildings required some modifications for enhanced comfort.

With time, the inhabitants of the area, Costa Ricans and afro descendants from the Antilles brought to build the railway, adopted the style, making their own adaptations to the construction of their homes. The center of Limón and its first expansion, known as Jamaica Town, were the two first areas where this type of vernacular architecture was developed.

Costa Rican Caribbean architecture is characterized for using timber material for the structure and enclosures, in which the "balloon frame" system stands out [2]. Large corridors and galleries, steep-sloped zinc roofing, double eaves, constructed high up on concrete or

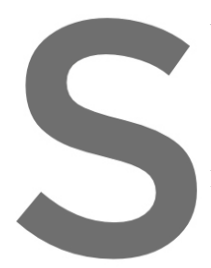
wooden piles, are its outstanding architectonic elements. In ad
decorations of Victorian influence, such as railings, lattices, w
corbels. Although constructions for mixed, commercial, religio
made, single-family and multifamily constructions were predon
In the past, these buildings proliferated in the city of Limón, and putting at risk the identity of the area. Although this type of architecture is characteristic of the Caribbean in Costa Rica and is linked to the historical urban landscape of the city of

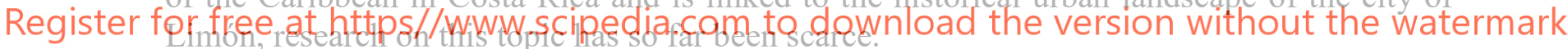

Hardly any literature regarding this topic is available, nor previous inventories to know the number and conditions of the constructions. Added to this, few buildings are protected by the government, which increases their risk of disappearing.

In addition to vulnerability to anthropic agents, these buildings are exposed to biodeterioration, being wood the main construction material, subjected to environmental conditions of high precipitation, humidity and temperature, as mentioned above. From this perspective, we focus on this topic as no previous work has been done in the country in terms of Costa Rican Caribbean architecture.

Since 2018, the Instituto Tecnológico de Costa Rica (TEC), through its schools of Architecture and Urbanism and Forest Engineering, together with the School of Biological Sciences at Western Illinois University (WIU), have been collaborating in the research project "Conservation of the Costa Rican Caribbean architecture by applying advanced techniques for the study of the causative agents of deterioration of buildings". The main objective of this project is "to promote the conservation of Costa Rican Caribbean architecture built within the urban historical center of the city of Limón (historical center and first expansion) between the period 1871-1940, based on the inventory, characterization and diagnosis of the causative 
agents of damage in the buildings". To this end, four specific objectives have been proposed to be developed over a period of four years, which are:

- Identify the Costa Rican Caribbean architecture within the temporal (between 18711940) and spatial delimitation (historical center and Jamaica Town neighborhood) proposed for research.

- Diagnose the signs of deterioration of the buildings selected.

- Analyze the causative agents of pathological processes detected in the laboratory.

- Propose alternatives for treating the damage detected using a pilot testing project.

This paper presents partial results of the research project. It focuses on showing the architectural, historic and constructive values of Costa Rican Caribbean architecture, as well as advancements with respect to identification of damage associated with biological agents in these buildings.

\section{METHODOLOGY}

The study and conservation of vernacular architecture requires a process that addresses two aspects: first, understanding its architectural and constructive elements; and secondly, developing a better knowledge of the causative agents that influences its deterioration. From a multidisciplinary vision, this research expects to raise awareness on a type of architecture that has long been undervalued, and at the same time, find possible solutions to its preservation. The steps carried out between 2018 and 2019 corresponding to the first three objectives are

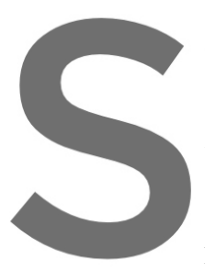
detailed below:

2.1. Review of availlable
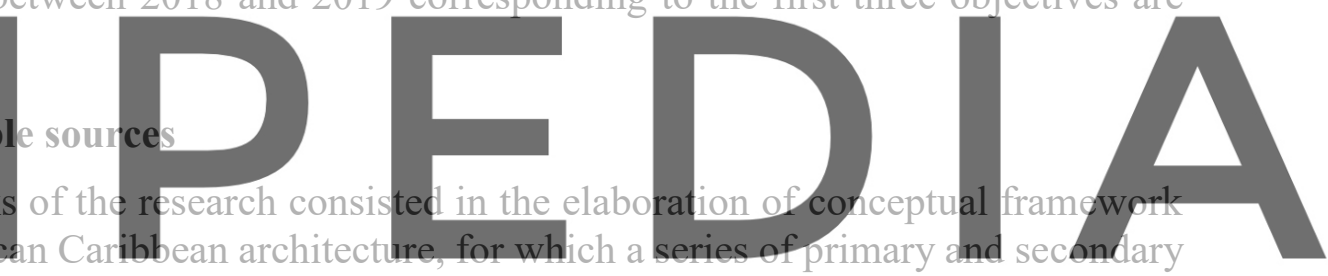

sources were consulted, such as books, magazines, catalogues, newsletters, maps, historical

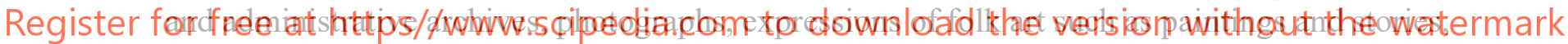
final graduation papers, among others. Mainly sources were consulted from public libraries in San José and Limón, National Archive of Costa Rica, National Library of Costa Rica, Library of ICOMOS Costa Rica, Centre for Research and Conservation of Cultural Heritage and university libraries.

Additionally, the cultural statistics of the Ministry of Culture and Youth linked to the subject of heritage were consulted to identify data on the situation regarding use of and state of conservation of the buildings under study, especially those declared Architectural Historical Heritage.

A review of literature related to biodeterioration and the protocols for the analysis of biological agents was also made.

\subsection{Systematization of the information}

The project was developed using a collaborative work methodology in which each one of the members contributed to the research according to their expertise. For this purpose, an online platform has been used (Google Drive), fed by all team members for the storage of information 
obtained and creation of a database where materials such as photographs, cartography, bibliographic references, etc. are stored.

On the other hand, the information obtained during the first two years of the project was used to create graphic material showing the characteristic elements identified of Costa Rican Caribbean architecture.

\subsection{Survey of on-site information and building inventory}

Between 2018 and 2019 a series of field trips were made to the city of Limón. The purpose was to gather on-site information to conduct the inventory of Costa Rican Caribbean architecture. Beforehand, a guide to gather information and the strategy to be followed during the fieldwork was designed. Next, the information collected was systematized in records.

\subsubsection{Initial listing}

A list of the buildings was made that compiled the fundamental characteristics of Costa Rican Caribbean architecture identified using the conceptual framework. Records were used to gather this information and the premises were georeferenced using the on-line software tool My Maps (https://www.google.com/intl/es/maps/about/mymaps/), which allowed including text and photographic information.

\subsubsection{Categorization of buildings}

Once the initial listing was completed, the buildings were categorized according to legibility presented were:

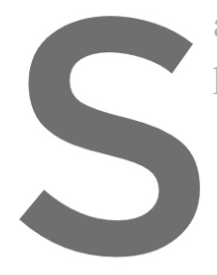
Type 1: Non-transformed oy slightly
the characteristics of Costa Rican C

- Type 2: Building characteristics of Costa Rican Carib
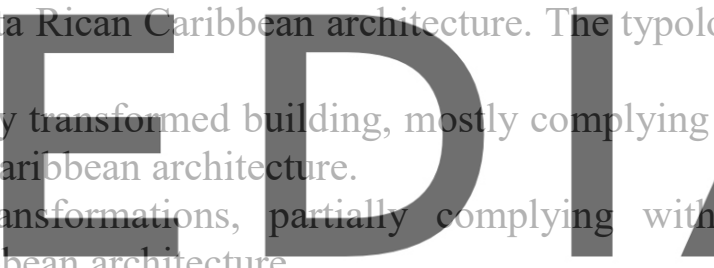

- Type 3: Very transformed building, conserves few characteristics of Costa Rican

Register for free atchttubshwy My Eeipedia.com to download the version without the watermark

- Type 4: Does not correspond to the object of study.

This activity allowed to establish a filter to identify the buildings that should be inventoried.

\subsubsection{Inventory}

The inventory included the buildings classified as types 1 and 2. The inventory records designed allowed collection of major information of each building in relation to the research objectives of the project. Among the data featured are: location; proprietors; architectonical, constructive and material characteristics; state of conservation; among others.

\subsubsection{Preliminary survey of damages and biological agents.}

Records were developed to survey the damage and biological agents present in the buildings inventoried. In addition, photographic records of the elements identified were made.

\subsubsection{Data organization}


Final records were prepared with the information obtained from the inventory and the preliminary survey of damages and biological agents, with the intention of documenting each of the buildings and to generate a formal document that compiles the inventory.

\subsubsection{Inventory revision}

A thorough inventory revision process has been carried out and in some cases involved a second visit to the field site to rectify information collected in the first visit and the new updated data was incorporated in the data files.

\subsubsection{Database}

The information of the inventory and the preliminary survey of damages and biological agents allowed the construction of a database of the buildings of Costa Rican Caribbean architecture present in the historical center of Limón and in Jamaica Town. This tool, in addition to facilitate information management, provides input to develop a multi-criteria evaluation and the creation of a Geographic Information System to support the selection of buildings for sampling and laboratory analysis.

\subsection{Identification of deterioration agents}

The process of identifying deterioration agents required the selection of a representative sample of the buildings initially identified as part of the inventory. To this end, a multi-criteria evaluation was carried out to prioritize the buildings.

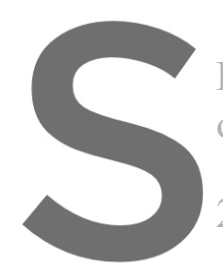

Once the buildings

Forest Pathology Laboratory cef of Fungal Ecology of WIU.

2.4.1. Multi-criteria evaluation
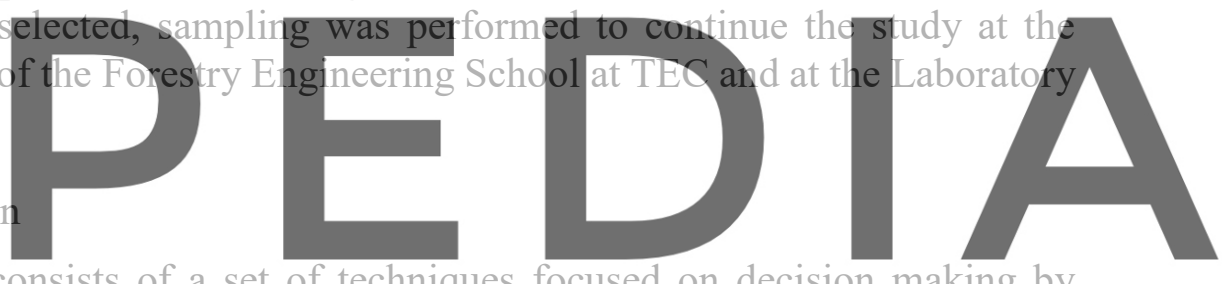

Multi-criteria evaluation consists of a set of techniques focused on decision making by

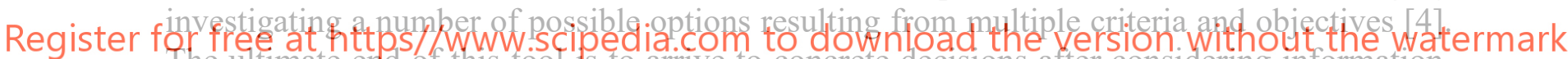
The ultimate end $5 f$ this tool ts to arrive to concrete decisions after considering information, objects and relationships [5].

The following criteria were established in the present work, and were assigned different percentages according to the interests of the project, weighing the value according to the building:

a) Legibility of the Costa Rican Caribbean architecture characteristics (30\%): In order to promote the conservation of this type of architecture, the proper reading of its characteristics is essential, so the first criterion is related to the categorization of previously addressed buildings. Buildings types 1 and 2 were used as they are the ones that best preserve the characteristics. Weighing was performed in conformance with the following aspects:

- Type 1: Non-transformed or slightly transformed building, mostly complying with the characteristics of Costa Rican Caribbean architecture (2 points).

- Type 2: Building with some transformations, partially complying with the characteristics of Costa Rican Caribbean architecture (1 point). 
b) Architectural Historical Heritage Declaration (20\%): This legal concept, contemplated in Law No. 7555 of Costa Rica, which identifies the country's buildings, public or private, whose cultural and historical significance makes their conservation important.

- Without declaration (0 points).

- With declaration (1 point).

c) Conservation state $(30 \%)$ : As a result of the inventory process, the record incorporated an in-depth assessment of the building components of the edifice. According to the list of the elements and their assessment, a higher score was given to those buildings with the greatest need for intervention.

- Good: The element is in good condition, conserves all or most of the formal and material characteristics of the time (1 point).

- Regular: The element exists but its state is inadequate, with some damage and signs of deterioration and modifications that are not consistent with the time ( 2 points).

- Bad: The element is in very bad condition, presenting damage and signs of deterioration. Its state needs immediate intervention (3 points).

d) Accessibility to the building (20\%): This criterion incorporates the possibility of going deeper into the study of the building.
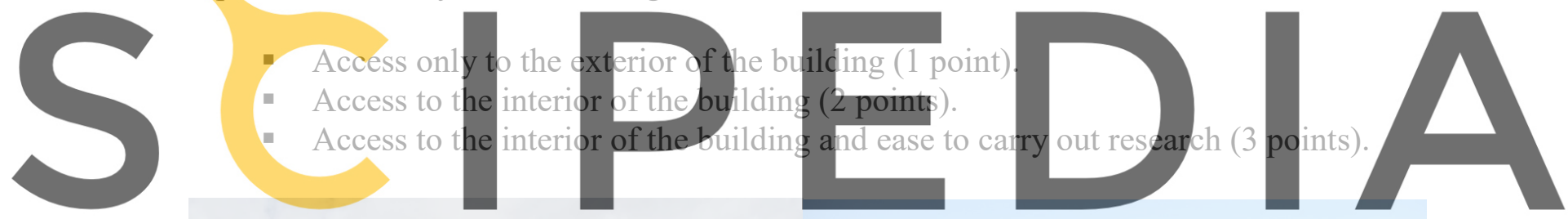

Register for free at https//www.scipedia.com to download the version without the watermark

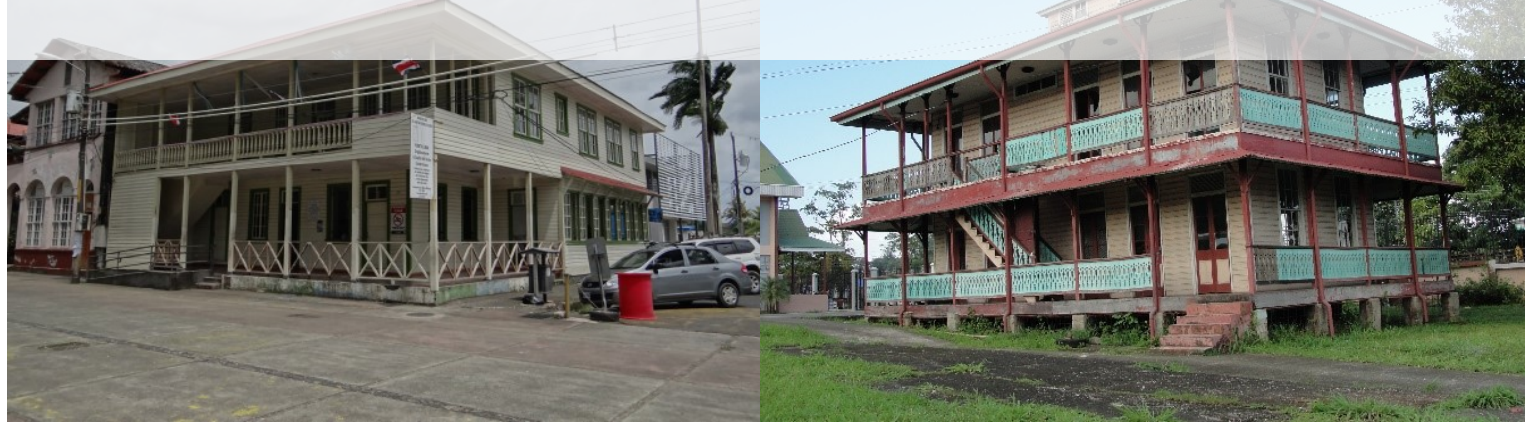

Figure 1. Antigua Capitanía de Puerto and the Casa Misionera de la Iglesia Bautista.

\subsubsection{Sampling and environmental monitoring}

Once the buildings were selected, and with the permission of the owners, the samples of areas with damage by potential biological agents were collected. As of December 2019, the sampling was carried out in the Antigua Capitanía de Puerto and in the Casa Misionera de la 
Iglesia Bautista (figure 1). Both buildings have a declaration of Architectural Historical Heritage. We plan to carry out this work in the other selected buildings in the first half of 2020 .

Two samples were taken per damaged area using sterile cotton swabs and another one by collecting approximately $1 \mathrm{~g}$ by scratching the exposed material. As part of the protocol, the damaged areas were sterilized with $70 \%$ alcohol. The samples were identified and stored for future use in the laboratory.

\subsubsection{Sampling processing in the laboratory}

The samples weighing $1 \mathrm{~g}$ were divided into two $(0.5 \mathrm{~g}$ each) in order to perform two types of analysis. The first procedure consisted in the isolating the microorganisms and the second was extraction of DNA for microbial identification, which is to be performed at Western Illinois University. The sample was stored at $-20^{\circ} \mathrm{C}$ to be sent later to the United States in DNA extraction buffer.

The samples were sterilized in a laminar flow chamber by soaking them into $1 \%$ sodium hypochlorite for a period of 30 seconds; then in $96 \%$ ethanol for 30 seconds; lastly, the sample was washed in sterile distilled water for one minute.

\subsubsection{Microorganism isolation}

The sterile samples were subdivided into three and placed on petri dishes with three types of culture media: potato dextrose agar (PDA), nutrient agar (NA) and Sabouraud agar (SA). These cultures were incubated for eight days at $25^{\circ} \mathrm{C}$; once incubation finished, the petri dishes were evaluated and hyphal tips were taken to perform a subculture of each fungus found untip obtaining an axenic cult 2.4.5 Microorganism identification
The axenic cultures obtained were characterized morphold will be extracted using a commercial kit DNeasy (Qiagen). Nex

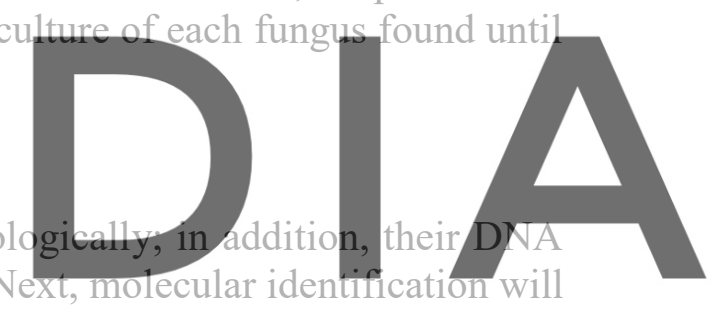
be performed using fungal specific primers at the Fungal Ecology Laboratory at WIU.

Register for free at https//Www.scipedia.com to download the version without the watermark 2.4.6. Environmental monitoring

Devices for environmental monitoring (dataloggers) were placed in each selected building to analyze variations in humidity and temperature throughout the research. In addition, measurements with a thermo-hygrometer and a laser measurer of surface temperature have been carried out during each visit to the buildings to complement datalogger information. The information thus gathered is expected to help establish relationships between humidity and temperature, and the presence of biological agents.

\subsection{Participatory process and community awareness}

As part of the project's tasks carried out, focal groups have been formed with social agents of the community that, because of their professional profile or connection with buildings of interest for the research, may be able to validate the information or contribute new data. In total, three focal groups were formed during the second semester of 2018 and the first semester of 2019. 
Additionally, an exhibition called "Limón Port: Valuing the Costa Rican Caribbean architecture" was produced, to present some of the first results from the research. Its purpose was to raise awareness in the population with respect to vernacular architecture.

\section{RESULTS}

Despite having performed an exhaustive bibliographic and documentary review of the relevant topics for the project, both the information found in primary and secondary sources and at documentation centers, archives and libraries, was scarce and lacked specialization in the subject addressed in the project. In this regard, there is a clear need to develop additional materials to address the topic of Costa Rican Caribbean architecture and give it the relevance it has as an identity element of this culturally diverse geographic region.

Nevertheless, the information gathered allowed a better understanding of the evolution of Limón's historical center and first urban expansion, and recognize the milestones in the development of the city and their relationship with the emergence of buildings with similar architectonic and construction characteristics. Hence, conceptual framework and a timeline were produced with respect to this topic in order to facilitate the interpretation and understanding the city's evolution.

Review of documents, among which the contributions of $[6,7,8,9]$ stand out, and the contrast between these and the information gathered in the site allowed to identify a series of essential characteristics linked to Costa Rican Caribbean architecture, as follows:

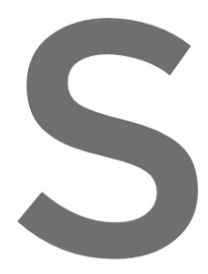

- Use of timber as the main construction material.

- Use of wodden or concrete piles, exposed or coverente facade.

Presence of attics.

Windows or

Outdoor corridors or galleries.

Presence of balconies.

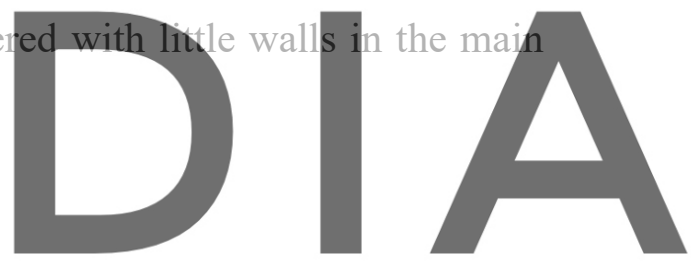

Register for free at httpls Use of eaves and similar structures in other areas separated from the roof, including

windows.

- Portico or covered lobby preceding the main access.

- Fretted wood decorations or gingerbread in the facade.

- Roofs with steep slopes.

- Use of corrugated metal sheets for the roofs.

- Strong colors in walls (mainly turquoise, green and pink).

- Wooden latticeworks (wooden grilles or petatillos) in the windows and in the upper part of the walls for cross air ventilation.

- Use of shutters.

- Central location of the building in the lot to leave free space at least in three of the sides, which is convenient for collecting rainwater and achieve improved ventilation.

- Thermal control chamber for insolation (monitor).

- Use of metal sheets as wall facings.

- Use of balloon frames. 
On the other hand, the information obtained allowed to establish the categories that would be used to classify the buildings found in the study area (figure 2). In this regard, it was found that, of all inventoried buildings, only $12 \%$ are type 1 , that is, they fully maintain the characteristics of Costa Rican Caribbean architecture since the interventions they present have not affected their image or spatial configuration. Part of this category are the Antigua Capitanía de Puerto and the Casa Misionera de la Iglesia Bautista, both buildings protected by the declaration of Architectural Historical Heritage.

Among the buildings, $23 \%$ were classified as type 2, as they have been partially intervened and have, to some extent, transformed their historical image. Some of them even suffered partial alteration of their materials with the addition of modern materials. Type 3 included 28\% of the buildings, which have been noticeably transformed and in some cases are given a different use from the original; some elements have been replaced, have suffered partial demolitions or have been intervened with modern materials, with only a few characteristics of Costa Rican Caribbean architecture remaining.

Type 4 included $19 \%$ of the buildings as they were not part of the object of study, despite being built with wood, they were from a more recent construction period than the established timeline for the project. The remaining 19\% of the buildings were not considered for inventory due to lack of information about them or access limitations.

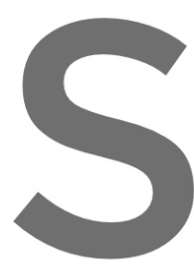

30
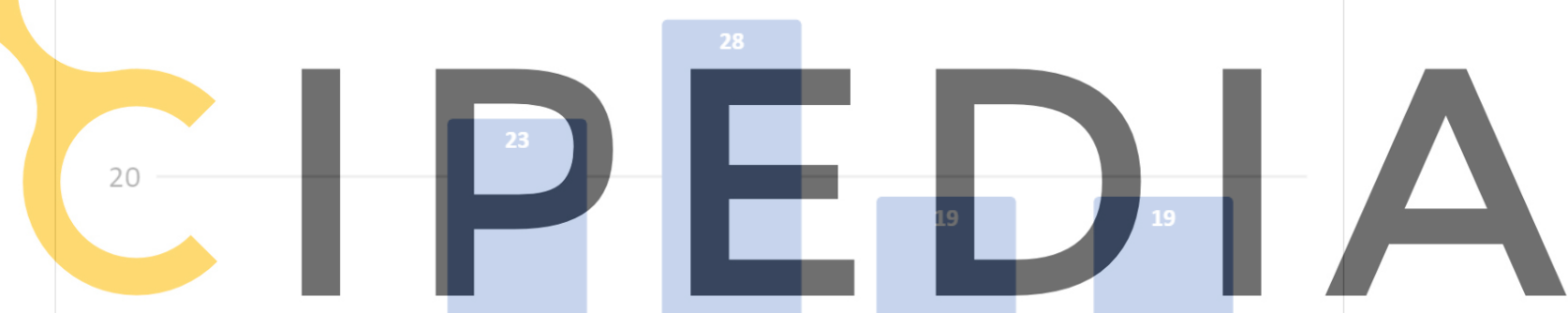

Register for free â https//www.scipedia.com to download the version without the watermark

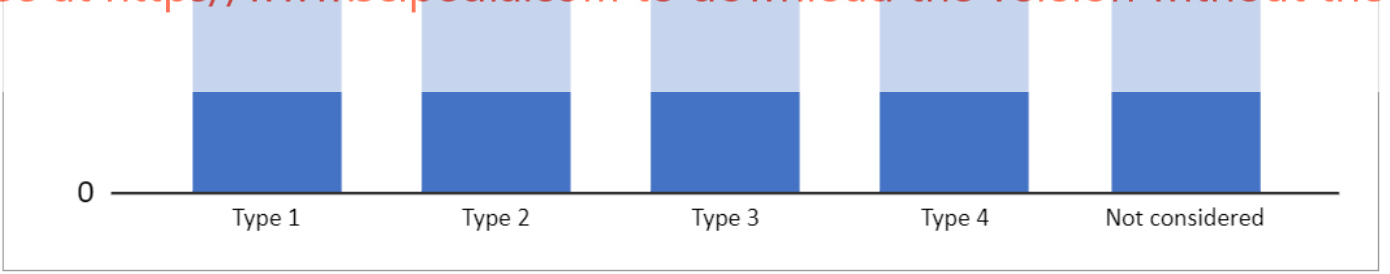

Figure 2. Classification of buildings found in the study area.

The building inventory of Costa Rican Caribbean architecture was carried out only with buildings types 1 and 2. In total, 30 buildings were recorded (figure 3). Each one of the records provides information about the state of conservation, architectural characteristics, types of damage found and causative agents.

The information in the inventory records and the database helped perform the multi-criteria evaluation to choose the buildings in which the sampling and environmental monitoring would be carried out. The multi-criteria evaluation helped determine the buildings of greatest interest for research and plan the sampling by prioritizing. The first five positions were taken by: Casa 
Misionera de la Iglesia Bautista (W-tipo1-01), Antigua Capitanía de Puerto (AAA-tipo1-01), Casa Garvey (TT-tipo1-01), multi-familiar housing (TT-tipo1-02) and multi-familiar housing (P-tipo1-01).

The process of sampling and monitoring has already begun in the first two buildings indicated. As of December 2019, a damage survey concerning biodeterioration agents had been carried out. This survey allowed the identification of at least 15 areas showing biological damaged in the Antigua Capitanía de Puerto and 24 in the Casa Misionera de la Iglesia Bautista.

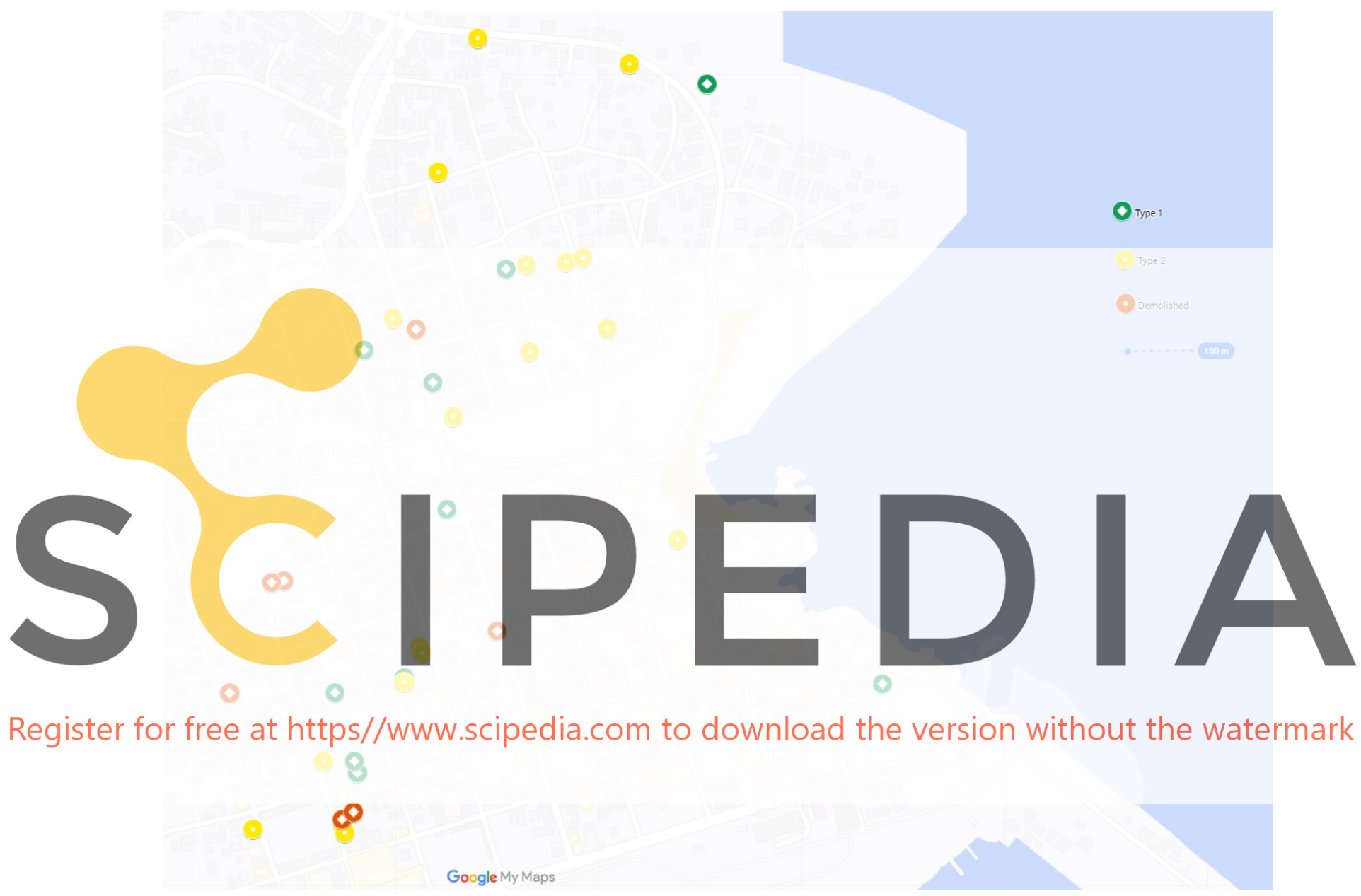

Figure 3. Map of inventoried buildings.

In total, 25 samples were collected in both buildings (11 and 14, respectively). As for the study of fungi associated with these damage structures, these are through a process of isolation and DNA extraction to be later identified. Although it was determined that both buildings are affected by termites, so far it has not been possible to find a living insect. DNA sequencing and analysis of the samples taken is being conducted by researchers at WIU, who are in the process of identifying the microorganisms, at the morphological and molecular level.

Dataloggers have already been placed in the two buildings and continuous environmental monitoring work is being carried out. The data has been collected and added to the project database for use in future stages. 
During these first two years of development, the project has generated a large amount of information that has been systematized into three main inputs: a 3D modelling of the buildings with heritage declaration and three private homes; an illustrated glossary of architectural terms and a guide with features of Costa Rican Caribbean architecture; the two latter ones aim to promote the use of technical language to refer to the different building elements and to graphically raise awareness on the particularities of this type of buildings. On the other hand, three-dimensional modelling will simplify the analysis of the climatic conditions of the buildings through the use of specialized software, while allowing the documentation of the buildings.

In order to promote appreciation of this architecture and appropriate the knowledge generated with this research, the exhibition "Limón Port: Valuing the Costa Rican Caribbean architecture" was produced. After this activity was organized, stakeholders have shown interest in launching initiatives related to the tourism sector to allow generation of endogenous development by valuing heritage resources; precisely at this point, an important relationship has been established with a new extension project also developed by TEC in relation to valuing heritage resources.

Lastly, during the development of this research the need arose to identify the varieties of wood present in the different building elements of the inventoried buildings; this process began during the second half of 2019 with the visit of specialists from the TEC School of Forestry Engineering; however, the work of identification will continue over the remaining implementation time of the project.

\section{CONCLUSIONS}

The limited information and lack of knowledge on Costa Rican Caribbean architecture makes its recognition at the professional level difficult. The same occurs with the processes of awareness and appropriation by the community. Research is required on this type of vernacular architecture from the historic, social and architectural perspectives.

During the period in which the research has been carried out, the demolition of seven type 1 and 2 buildings has already been recorded, as a result of poor state of conservation and pressures from urban development. Of these, five buildings could be documented in the initial listing and two of them have inventory records; thus, the vulnerability of this architecture remains exposed.

Of the 30 buildings inventoried by the project only two have a declaration of Architectural Historical Heritage, which means they are protected by the Government; however, this has not guaranteed their conservation either. The remaining buildings, according to the inventory carried out and the multi-criteria analysis, show that most of them are in a bad or regular condition. This should serve to call attention on preserving and valuing these buildings, looking for options to promote the search for solutions from a multidisciplinary perspective that also contemplates the in-depth study of causative agents of damage.

The progress of the research has made it possible to identify a number of microorganisms potentially associated with biodeterioration. The next stage of the project will delve deeper into the morphological and molecular analysis of these microorganisms in order to propose solutions to the pathological processes detected. 
Acknowledgements. We thank the Vicerrectoría de Investigación y Extensión of the Instituto Tecnológico de Costa Rica for their support to this project. We also thank the rest of the research team (Ing. Dawa Méndez-Álvarez, PhD. Andrea Porras-Alfaro, Arch. Dominique Chang-Albizurez, Arch. Enmanuel Salazar-Ceciliano and Arch. Mauricio Guevara-Murillo) and assistant students (Fernando Agüero-Bravo, Sofía Rivera-Villareal, Gerald Cordero-Arias, Rafael Hidalgo-Campos, Gabriela Delgado-Hernández, Rebeca Gómez-Oviedo, Alejandro Varela-Fonseca, Carolina Jiménez-Vargas, Angie Rodríguez-Rosales) who have actively worked in the development of the research activities.

\section{REFERENCES}

[1] García, K. El patrimonio cultural como base para un modelo de desarrollo endógeno. La herencia cultural del Período Liberal en Costa Rica (1870-1940) como capital cultural. Un estudio de caso. Tesis Doctoral. Universidad Autónoma de Madrid, (2016).

[2] Sanou, O. y Quesada, F. Orden, progreso y civilización (1871-1914). Transformaciones urbanas y arquitectónicas. En E. Fonseca y J. Garnier (Eds.): Historia de la Arquitectura de Costa Rica. Museos del Banco Central y Centro de Investigaciones Históricas de Centroamérica (1998).pp. 219-317.

[3] Woodbridge, R. Historia de la arquitectura en Costa Rica. Editorial Tecnológica de Costa Rica, (2003).

[4] Barredo, J. Sistemas de Información Geográfica y Evaluación Multicriterio en la Ordenación del Territorio. Editorial Ra-Ma. I edición, (1996).

[5] Munda, G. Teoría de Evaluación Multicriterio: una breve perspectiva general. Maestría en Economía Ecológica y Gestión Ambiental. Ed. Universidad Autónoma de Barcelona, (1998).

[6] Gutiérrez, S. Arquitectura caribeña: Puerto Limón, Bocas del Toro. Escala, (1991).

[7] Barascout, E. Anteproyecto de Revitalización del Centro Histórico de Limón. ICOMOS, (1995).

[8] Vives, I. Arquitectura de la Época de la "United" 1890-1930. Patrimonio (2004) 4: 95-109. San José: Centro de Investigación y Conservación del Patrimonio Cultural. 95-114.

[9] Sanou, O. Guía de arquitectura y paisaje de Costa Rica. Junta de Andalucía, (2010). 